LWSA

Local Wisdom, Social, and Arts

PAPER - OPEN ACCESS

\title{
Gambaran Perilaku Membeli Produk Pakaian Online di Kalangan Remaja
}

$\begin{array}{ll}\text { Author } & : \text { Lasma Yulianti N } \\ \text { DOI } & : 10.32734 / \text { lwsa.v1i1.170 } \\ \text { Electronic ISSN } & : 2654-7058 \\ \text { Print ISSN } & : 2654-7066\end{array}$

Volume 1 Issue 1 - 2018 TALENTA Conference Series: Local Wisdom, Social and Arts

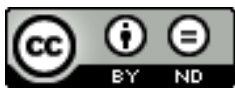

This work is licensed under a Creative Commons Attribution-NoDerivatives 4.0 International License.

Published under licence by TALENTA Publisher, Universitas Sumatera Utara
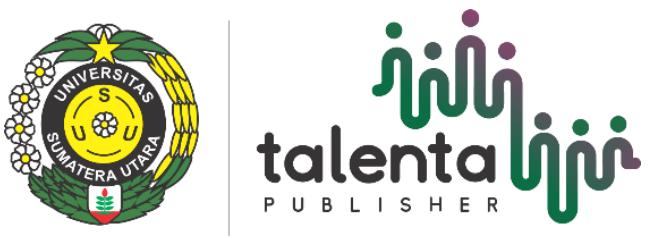


\title{
inili talentalioi TALENTA Conference Series \\ P U B L I S H E R Available online at https://talentaconfseries.usu.ac.id \\ Gambaran Perilaku Membeli Produk Pakaian Online di Kalangan Remaja
}

\author{
Lasma Yulianti Na, Sherry Hadiyani ${ }^{\mathrm{a}}$ \\ ${ }^{a}$ Fakultas Psikologi, Universitas Sumatera Utara, Medan 20155 \\ sherryhadiyani@gmail.com
}

\begin{abstract}
Perilaku membeli merupakan kegiatan dalam mendapatkan atau menggunakan barang atau jasa baik secara langsung maupun tidak langsung yang bertujuan untuk memenuhi kebutuhan.Perkembangan teknologi informasi disertai mudahnya mengakses internet menyebabkan para produsen melakukan pemasaran produknya melalui internet sebagaimana disebut dengan ecommerce.Kemudahan akses dan banyaknya pilihan semakin mendorong konsumen untuk melakukan pembelian produk secara online. Hasil riset Asosiasi Penyedia Jasa Internet Indonesia (APJII)menunjukkan bahwa remaja adalah mayoritas pengguna internet di Indonesia dengan berbagai macam kegiatan yang bisa mereka lakukan salah satunya adalah berbelanja online.Remaja yang berada pada tahap imagery audience ingin selalu diperhatikan oleh lingkungan sekitarnya sehingga mereka membutuhkan atribut-atribut agar dapat diakui oleh lingkungan, salah satunya adalah pakaian. Oleh karena itu, penelitian ini difokuskan pada perilaku membeli produk pakaian onlinedi kalangan remaja. Penelitian ini menggunakan teknik statistik dekriptif. Subjek penelitian ini adalah siswa-siswi SMA Santo Thomas 1 Medan berjumlah 290 orang. Alat ukur yang digunakan adalah skala perilaku membeli yang disusun berdasarkan aspek perilaku membeli yang dikemukakan oleh Kotler (2008). Hasil penelitian ini menunjukkan bahwa gambaran perilaku membeli produk pakaian online subjek berada pada kategori sedang.
\end{abstract}

Kata Kunci: Perilaku membeli, Pakaian Online, Remaja

\section{Pendahuluan}

Pembelian suatu produk baik itu pakaian, barang elektronik dan lain sebagainya semakin mudah dilakukan pada era globalisasi sekarang ini. Perkembangan teknologi informasi yang semakin meningkat disertai dengan semakin mudahnya mengakses internet membuat para produsen banyak melakukan pemasaran produknya melalui internet sebagaimana disebut dengan e-commerce. Pratiwi (2014) dalam artikelnya mengungkapkan jumlah transaksi ecommerce di Indonesia pada tahun 2013 mencapai USD 8 milliar, pada tahun 2014 mencapai angka USD 12 milliar, dan pada tahun 2015 jumlah transaksinya meningkat mencapai USD 20 milliar. Artikel tersebut juga menjelaskan bahwa pengguna internet di Indonesia saat ini mencapai 74 juta orang yang diperkirakan pada tahun 2016 ini akan mencapai angka102 juta orang. Hal ini semakin mendukung kelancaran pertumbuhan e-commerce di Indonesia.

Kemudahan akses dan banyaknya pilihan semakin mendorong konsumen untuk berbelanja secara online. Dikutip dari artikel yang ditulis oleh Sanjaya (2013), hasil survey MarkPlus Insight Indonesia Netizen Survey 2013 menunjukkan bahwa ada tiga jenis barang yang paling sering dibeli oleh konsumen yaitu, pakaian, sepatu dan tas. Sebanyak 67,1\% responden mengaku mereka membeli pakaian secara online, 20,2\% membeli sepatu dan $20 \%$ membeli tas. Berbelanja secara online kini sudah menjadi trend dan kebiasaan masyarakat Indonesia. Ahmad (2014) 
pada artikelnya menyertakan data hasil survey Google bekerjasama dengan TNS online dan situs belanja online yaitu Blibli.com. Survey ini dilakukan pada 1.300 responden, di 12 kota besar yang salah satunya adalah Medan dan jenis kelamin laki-laki dan perempuan di rentang usia 18-50 tahun yang mana dalam rentang tersebut juga terdapat usia remaja. Hasil survey tersebut menunjukkan bahwa produk pakaian kini paling banyak dibeli secara online. Setidaknya ada 51\% dari total 1.300 responden yang membeli produk pakaian secara online setiap bulannya. Berdasarkan beberapa hasil survey tersebut, memperkuat peneliti untuk memfokuskan penelitiannya pada produk pakaian online.

Kegiatan-kegiatan konsumsi, pembelian produk baik itu secara online maupun pembelian langsung ke toko inilah yang disebut sebagai bagian dari perilaku membeli. Engel et al. (1995) mendefenisikan perilaku membeli sebagai tindakan yang langsung terlibat dalam merencanakan, membeli dan menggunakan barang atau jasa. Menurut Walgito (2003) perilaku membeli itu tidak timbul dengan sendirinya, tetapi sebagai akibat dari stimulus yang diterima oleh individu yang bersangkutan, baik stimulus eksternal atau internal. Beberapa faktor yang mempengaruhi perilaku membeli ini antara lain (Kotler, 2008) : budaya, sosial, karakteristik pribadi dan kondisi psikologis pembeli. Ketiga memiliki pengaruh tersendiri pada konsumen saat melakukan pembelian.

Pada faktor karakteristik pribadi, memuat usia konsumen. Dalam hal ini perilaku membeli bisa terjadi pada siapa saja termasuk usia remaja. Menurut Papalia et al. (2007) masa remaja adalah masa transisi dari masa kanak-kanak ke masa dewasa yang melingkupi 3 perkembangan utama, yaitu fisik, kognitif, dan psikososial. Fenomena perilaku membeliketika dikaitkan kepada konsumen yang berada di tahap perkembangan remaja ini menjadi menarik untuk diteliti mengingat di masa remaja tersebut merupakan masa peralihan, yang mana kondisi emosional dan mentalnya juga belum stabil sehingga mereka bisa berbelanja produk apapun yang mereka inginkan. Johnstone (dalam Mangkunegara, 2002) mengungkapkan beberapa karakteristik dari konsumen remaja, yakni remaja sangat mudah terpengaruh rayuan penjual, mudah terbujuk rayuan iklan, tidak berpikir hemat dan kurang realistis. Hal ini semakin memperkuat kemungkinan terjadinya perilaku membeli pada remaja.

Remaja juga merupakan salah satu pengguna aktif internet. Maulana (2015) memaparkan hasil riset nasional yang dilakukan oleh Asosiasi Penyedia Jasa Internet Insonesia (APJII) dan Pusat Kajian

Komunikasi Universitas Indonesia yang menunjukkan hasil bahwa mayoritas pengguna internet Indonesia berada di rentang usia 16-25 tahun. Hasil riset tersebut menunjukkan bahwa remaja menjadi mayoritas pengguna internet di Indonesia dengan berbagai macam kegiatan yang bisa mereka lakukan salah satunya adalah berbelanja online. hasil survei yang dilakukan oleh perusahaan penyedia teknologi pembayaran yaitu Visa, menunjukkan bahwa para pembeli online ini cenderung berusia lebih muda dari para pembeli offline. Hampir separuh pembeli online tersebut berusia 1630 tahun. Hal ini membuktikan bahwa banyak remaja yang berbelanja via online dan memperbesar kemungkinan perilaku membeli remaja saat berbelanja online.

Castelbury et al (dalam Beaudoin et al, 2006) mengatakan remaja berada dalam tahap imagery audience dimana remaja selalu merasa dirinya diperhatikan lingkungan sekitarnya. Remaja memperhatikan penampilan dan cara berpakaian sesuai dengan dirinya. Oleh karena itu, maka mereka butuh atribut-atribut agar dapat diakui oleh lingkungan, salah satunya adalah dengan menggunakan produk-produk pakaian. Kaphener et al (dalam Beaudoin et al, 2006) mengatakan bahwa banyak remaja yang melakukan pengeluaran yang lebih dari biasanya hanya untuk memakai dan menggunakan produk yang sesuai dengan dirinya. Hal ini memperkuat kemungkinan remaja dalam membeli produk pakaian tersebut.

Seperti yang telah diungkapkan diatas, penggunaan e-commerce yang semakin meningkat di Indonesia memicu terjadinya pembelian secara online yang juga terbukti dari data yang didapatkan bahwa semakin banyaknya masyarakat Indonesia yang melakukan pembelian berbagai macam produk secara online terutama pakaian. Konsumen yang pada penelitian ini dikhususkan pada remaja yang mana kondisi emosi dan kognitifnya masih belum stabil, dan banyaknya remaja yang menjadi pengguna internet dan berbelanja online juga mendukung terjadinya perilaku membel saat berbelanja online, salah satunya produk pakaian online.

Oleh karena itu, peneliti tertarik untuk melakukan penelitian mengenai gambaran perilaku membeli produk pakaian online di kalangan remaja. 


\section{Metode Sampel}

Partisipan dalam penelitian ini berjumlah 290 orang siswa-siswi SMA Santo Thomas 1 Medan yang terdiri dari 118 orang laki-laki dan 172 orang perempuan. Partisipan berada dalam rentang usia 14-18 tahun. Teknik sampling yang digunakan adalah proportional stratified sampling, yang membagi siswa berdasarkan kelasnya masing-masing.

\subsection{Prosedur dan Alat Ukur}

Peneliti membuat alat ukur perilaku membeli berdasarkan 4 aspek perilaku membeli yang disusun oleh Kotler (2008) yaitu pengenalan kebutuhan, pencarian informasi, evaluasi alternatif dan perilaku setelah membeli. Dari 32 aitem terdapat 25 aitem yang dapat dijadikan skala dalam penelitian dengan cronbach alpha sebesar 0,82 .

\section{Hasil}

Hasil penelitian ini menunjukkan gambaran perilaku membeli 290 orang subjek dari SMA Santo Thomas 1 Medan dengan mean sebesar 64,2 yang menunjukkan perilaku membeli subjek terhadap produk pakaian online berada di kategori sedang. Skewness dan kurtosis bernilai 0,31 dan 0,16 yang menunjukkan bahwa data terdistribusi normal.

\subsection{Pembahasan}

Tujuan dari penelitian ini adalah untuk mengetahui gambaran dari perilaku membeli produk pakaian online di kalangan remaja. Hasil utama penelitian ini menunjukkan bahwa mean dari data perilaku membeli adalah sebesar 64,2 yang berarti rata-rata subjek memiliki tingkat perilaku membeli yang berada pada kategori sedang. Hasil perhitungan SPSS juga menunjukkan data terdistribusi normal yang dibuktikan dari skewness dan kurtosis yang mendekati nol yaitu sebesar 0,31 dan 0,16 .

Hasil penelitian ini didukung oleh Setiadi (2003) yang mengemukakan bahwa konsumen yang memiliki pengalaman yang positif dengan suatu produk akan lebih memungkinkan untuk melakukan pembelian. Selain itu, hasil penelitian ini juga diperkuat dengan penelitian yang dilakukan Martin (dalam Arnould et al, 2005) yang menemukan bahwa perasaan, ide dan sikap yang dimiliki konsumen terhadap suatu produk aspek penting dalam perilaku pembelian. Arnould, Price et al (2005) mengemukakan bahwa suatu produk akan dibeli konsumen jika konsumen tersebut merasakan ada hubungan simbolis yang sama antara produk tersebut dengan gambaran diri konsumen.

Dari perhitungan SPSS juga didapat bahwa subjek yang berjenis kelamin laki-laki sebagian besar memiliki tingkat perilaku membeli yang sedang yaitu sebesar 39\%. Begitu juga dengan subjek yang berjenis kelamin perempuan sebagian besar memiliki tingkat perilaku membeli yang sedang yaitu sebesar $43,07 \%$.

Untuk mendapatkan informasi lebih, maka peneliti melakukan komunikasi personal dengan salah satu siswa SMA Santo Thomas 1 Medan. "aku sering belanja online kak, seringnya sih belanja baju-baju mereknya macam-macam kak, yang banyakan gak dijual di mall-mall sini. Aku senang sih kak belanja kek gitu lebih enak nengok barangnya bisa sambil duduk bisa sambil tiduran pun bisa aku belanja kak lebih simple, sampe terkadang saking sukanya aku belanja ga karukaruan kak, habis duit jajan aku gak sadar kak...” (Komunikasi Personal, April 2016)

Berdasarkan hasil wawancara diperoleh keterangan bahwa subjek sering berbelanja pakaian secara online karena kemudahan dalam berbelanja online tersebut. Subjek juga kerap kali berbelanja berlebihan tanpa disadari saat berbelanja online.

Hasil penelitian ini harus diinterpretasikan berdasarkan situasi pada saat penelitian berlangsung.

Data dikumpulkan pada tanggal 8 April hingga 15 April 2016 sehingga hasil yang diperoleh mengenai perilaku membeli produk pakaian online di kalangan remaja menggambarkan fenomena yang saat itu sedang berlangsung.

\section{Kesimpulan}

Berdasarkan hasil analisis data yang diperoleh dalam penelitian ini, maka dapat diambil kesimpulan bahwa gambaran perilaku membeli subjek sebagian besar berada di kategori sedang. Yang berarti bahwa rata-rata subjek memiliki tingkat perilaku membeli yang sedang terhadap produk pakaian online. 
Disarankan bagi peneliti selanjutnya, yang berminat meneliti variabel tersebut untuk mengkaji faktor-faktor lain yang berhubungan atau sekiranya mempengaruhi variabel tersebut serta bisa mengganti atau memperluas sampel penelitian juga untuk lebih memperhatikan fenomena maupun faktor lain yang tidak diteliti dalam penelitian ini berkaitan dengan produk pakaian online.

\section{Referensi}

[1] Ahmad, Fahrur. (2014). Produk Apparel Ternyata yang Paling Dicari Konsumen Online Baru.

[2] netpreneur.co.id. Diakses tanggal 20 Oktober 2015.

[3] Arikunto, S. (2006). Prosedur Penelitian Suatu Pendekatan Praktik. Jakarta: Rineka Cipta. Azwar, S. (2009). Metode Penelitian. Yogyakarta: Pustaka Pelajar.

[4] Beaudoin, P., Lachance M.J. (2006). Determinants of Adolescents' Brand Sensitivity to Clothing. Family and Consumer Sciences Research Journal.

[5] Bennet, P.D. (1988). Marketing. New York: Mc Graw Hill Book Company.

[6] Chaplin, J.P. (1999). Kamus Psikologi. Alih Bahasa: DR. Kartini Kartono. Jakarta: PT. Raja Grafindo. Engel, J.F., Blackwell, R.D., \& Miniard, P.W. (1995). Consumer Behavior. Orlando: The Dryden Press.

[7] Feldman, R.S. (2012). Pengantar Psikologi: Understanding Psychology. Edisi 10. Jakarta: Salemba Humanika.

[8] Haye, De La \& Dingwall,C. (1996). Surfers, Skinheads \& Skaters. London: Victoria \& Albert Museum. Hebdige, Dick. (1991). The Meaning Of Style. London: Rouledge.

[9] Hurlock. E.B. (1992). Developmental Psychology: A Life Span Approach. 5th Edition. New York: McGraw Hill.

[10] Jusuf, Herman. (2001). Pakaian Sebagai Busana: Kajian Teoritik Tentang Fungsi dan Jenis Pakaian Dalam Konteks Semiotika. Jurnal Seni Rupa dan Desain. Bandung: STISI Telkom. Vol.1 No.3.

[11] Kawani. (2015). Manisnya Pasar E-commerce di Indonesia. feednik.com. Diakses tanggal 28 Agustus 2015.

[12] Kotler, Philip. (2008). Marketing Essentials. London: Prentice-Hall.

[13] Mangkunegara, Anwar P. (2002). Perilaku Konsumen. Edisi Revisi. Bandung: Refika Aditama.

[14] Maulana, Adhi. (2015). Pengguna Internet di Indonesi didominasi Remaja \& Wanita.

[15] tekno.liputan6.com. Diakses tanggal 20 Januari 2016.

[16] Morris, Desmond. (1977). Manwalking: Field Guide to Human Behavior. New York: Harry N. Abrams, Inc. Publisher.

[17] Papalia, D.E., Olds. S.W., \& Feldman R.D. (2007). Human Development. 10th Edition. New York: McGraw Hill Companies.

[18] Poerwadarminta, W.J.S. (1990). Kamus Bahasa Indonesia. Jakarta: Balai Pustaka.

[19] Pratiwi, Hesti. (2014). Potensi dan Tantangan E-commerce Indonesia Tahun 2015. dailysocial.net. Diakses tanggal 20 Oktober 2015.

[20] Salim, P. Salim, Y. (1991). Kamus Bahasa Indonesia Kontemporer: Edisi I. Jakarta: Penerbit Modern English Press.

[21] Sanjaya, Summase. (2013). Tiga Jenis Produk Plaing Sering dibeli Konsumen Secara Online. tokoina.com. Diakses tanggal 20 Oktober 2015.

[22] Santrock, J.W. (2003). Life-Span Development. 12th Edition. New York: Mc Graw Hill.

[23] Sari, Elisa V. (2014). OJK: Pendapatan Meningkat, Masyarakat Cenderung Konsumtif. cnnindonesia.com. Diakses tanggal 28 Agustus 2015.

[24] Setiadi, Nugroho J. (2003). Perilaku Konsumen, Konsep dan Implikasi Untuk Strategi dan Penelitian Pemasaran. Bogor: Kencana.

[25] Sugiyono. (2008). Statistika Untuk Penelitian. Bandung: Alfabeta.

[26] Sutriyanto, Eko. (2014). Remaja Indonesia Makin Royal Belanja Via Online. tribunnews.com. Diakses tanggal 20 Januari 2016.

[27] Swastha, Basu. (1984). Azas-azas Marketing, Edisi ke-3. Liberty: Yogyakarta.

[28] Walgito, B. (2003). Psikologi Sosial Suatu Pengantar: Edisi Revisi Kedua. Yogyakarta: Andi Offset. 